https://helda.helsinki.fi

\title{
Precarious Times for Central Asian Migrants in Russia
}

\section{Eraliev, Sherzod}

2020-10

Eraliev , S \& Urinboyev , R 2020 , ' Precarious Times for Central Asian Migrants in Russia ' , Current History , vol. 119 , no. 819 , pp. 258-263 . https://doi.org/10.1525/curh.2020.119.819.258

http://hdl.handle.net/10138/321040

https://doi.org/10.1525/curh.2020.119.819.258

unspecified

publishedVersion

Downloaded from Helda, University of Helsinki institutional repository.

This is an electronic reprint of the original article.

This reprint may differ from the original in pagination and typographic detail.

Please cite the original version. 
"Normalized precarity should no longer be seen as something extraordinary, but rather as a way of life for millions of Central Asian migrants in Russia in the COVID-19 era."

\title{
Precarious Times for Central Asian Migrants in Russia
}

\author{
SHERzod ERALieV And Rustamjon URinboyeV
}

$\mathrm{T}$ he COVID-19 pandemic has had an immediate and unprecedented impact on the everyday lives of Central Asian migrant workers in Russia. But their working and living conditions were dire well before the pandemic, due to ever-tightening immigration rules, widespread police corruption, xenophobia, and a struggling economy.

In the course of our extensive fieldwork in Russia, we have observed how Russia's economic decline since 2014 has affected labor migration from Central Asia, and how migrants have coped. The pandemic has added a new array of uncertainties and challenges, including deepening antimigrant sentiment.

Traditionally regarded as a country of emigration, Russia has become one of the world's main migration magnets since the collapse of the Soviet Union. It is now the fourth-largest recipient of migrants in the world, after the United States, Germany, and Saudi Arabia. Russia's visa-free entry for almost all citizens of other post-Soviet countries (except the Baltic states, Turkmenistan, and Georgia), higher living standards, relatively better economic opportunities, and aging population have provided fertile ground for large-scale migratory flows from across the former Soviet Union.

For the past two decades, labor mobility between Central Asia and Russia has become well established and resilient in spite of economic crises and tightened immigration laws. But times have been hard since Western countries imposed

SHERZOD ERALIEV is a postdoctoral researcher with the Aleksanteri Institute at the University of Helsinki. RUSTAMJON URINBOYEV is a senior researcher at the Aleksanteri Institute and an associate professor in the Department of Sociology of Law at Lund University. sanctions on Russia following its 2014 annexation of Crimea and military intervention in eastern Ukraine. Coming in the wake of a substantial devaluation of the ruble and a drop in the price of oil (the country's main source of export revenue), the sanctions tipped Russia into a recession. For many migrants, the situation was worsened by the government's increasingly punitive measures to curb undocumented migration.

Experts estimate the total number of migrants in Russia at six to seven million. The majority come from three Central Asian countries: Kyrgyzstan, Tajikistan, and Uzbekistan. In 2019, there were more than two million Uzbeks, over one million Tajiks, and about 700,000 Kyrgyz nationals in Russia. Since Kyrgyzstan became a member of the Moscow-led Eurasian Economic Union (EEU) in mid-2015, its citizens, in theory, have the same labor rights as the local Russian populationthough Kyrgyz still face widespread violations of those rights as well as police extortion. Uzbekistan and Tajikistan do not belong to the bloc.

Migrant workers in Russia are mainly engaged in low-paid jobs, doing unskilled heavy labor. Many migrants are seasonal workers: they typically arrive in Russia in the spring, when economic activity picks up and more jobs are available at construction sites and on farms. They return to their home countries in late autumn, before coming back again in spring the next year.

While men typically find jobs in the construction, transportation, and agricultural sectors, women are predominantly employed in the retail trade (supermarkets and grocery stores, for example), catering, and domestic and cleaning services. Men still comprise a large majority of migrants, but the number of female migrants, especially from Kyrgyzstan, has increased considerably in recent years. 
The population of Central Asian migrant workers in Russia declined during the economic crisis that began in 2014, as the cost of entry into the official labor market increased. In 2015, the numbers of Uzbek and Tajik workers in Russia fell by 22.2 percent and 15.6 percent, respectively. The number of Kyrgyz workers increased by 5.4 percent over the same period, but that was likely a result of employment restrictions easing due to Kyrgyzstan's membership in the EEU.

In 2013, remittances from Russia-money sent home by migrants-totaled $\$ 7.8$ billion to Uzbekistan, $\$ 3.9$ billion to Tajikistan, and $\$ 2.1$ billion to Kyrgyzstan. By 2015, those figures dropped by almost half for Uzbekistan and Tajikistan, and by one-third for Kyrgyzstan.

A small number of migrants who returned home changed their preferred destinations from Russia to alternative migration hubs such as Turkey and Kazakhstan. (Central Asians can enter both Kazakhstan and Turkey without a visa.) However, as Russia's economic outlook started to improve and the Turkish and Kazakh economies experienced turbulence of their own,

Central Asian migrants soon returned to Russia, where huge construction projects such as building infrastructure for soccer's 2018 World Cup created tens of thousands of jobs for migrants.

The COVID-19 pandemic has once more revealed the vulnerable position of migrants in Russia. Thousands, if not tens of thousands, have lost their jobs. Others have been forced to work in precarious conditions, putting their health at risk.

\section{LIVING IN THE SHADOWS}

Although Central Asian migrants enter Russia legally, they often fail to comply with immigration laws and become undocumented. Formal rules and requirements for residency and employment of foreign citizens are complex and subject to constant change, making it nearly impossible for migrant workers to operate legally in the Russian labor market. Faced with inconsistent enforcement of immigration laws, many Central Asians are compelled to find jobs in the shadow economy, where they can get by without documents.

Alarmed by the growing undocumented migrant labor force, Russian authorities further tightened the laws, strengthened border infrastructure, and introduced highly punitive enforcement provisions.
Between 2012 and 2015, more than 50 laws and regulations aimed at reducing undocumented migration were amended to add administrative and criminal penalties for violations. Among these, an outright ban on reentry for some migrants (first introduced in 2013 and subsequently revised in 2014-15) was the most severe sanction that could be imposed on foreign citizens who had committed two or more administrative offenses within a threeyear period.

Another new law, known as the 90-180 rule, took effect in January 2014, stipulating that foreigners can stay in Russia for only 90 days within any 180-day period. Migrants who overstay are subsequently banned from entering Russia for three, five, or ten years, depending on the length of their overstay. These restrictions made it impossible for migrants to continue the common practice of crossing the border every three months in order to reenter and start a new grace period.

An additional legislative change stripped the Federal Migration Service of its status as an independent government agency. It was merged into the Ministry of Internal Affairs in early 2016, reflecting a shift toward a policing approach to migration management. Migration officials became de facto police officers without uniforms.

No evidence indicates that these measures produced the desired effect. There was a small drop in the number of migrants, but that was more a result of Russia's recession in the fall of 2014 than a demonstration of the effectiveness of harsher enforcement. In fact, the more restrictive immigration laws and policies led to the proliferation of ambiguous legal statuses and illegal-document schemes. Migrants learned to sidestep restrictions by buying "new passports" or "clean fake" immigration papers (counterfeits almost impossible to detect) from the numerous "legalizing firms" operating in Russia.

As they adapted to the tighter restrictions, migrants also began limiting their return trips home, planning one long stay in Russia during which they would try to earn as much as possible, knowing that they might not be allowed to reenter if they left the country. This trend showed up in the reduced frequency of border crossings. Many migrants began overstaying in Russia, increasing the share of undocumented foreigners in the labor market. 
Russian authorities estimated that there were around two million undocumented migrants in the country by the end of 2018. Rather than reducing their numbers, the hardened legal restrictions and punitive measures were contributing to the growth of undocumented migration.

\section{PATENT PENDING}

One of the most important changes in the Russian migration regime over the past five years has been the introduction of a new work permit system. In 2015, Russia abolished the previous system of work permit quotas for citizens from the visa-free post-Soviet countries and introduced new permits, known as patents, that cover all forms of migrant employment.

Until then, migrants could use a patent only for entering into employment agreements with individual citizens for personal, household, or other similar services. Under the new system, as of January 1,2015 , patents became the main channel for legal employment for all foreign workers entering Russia under the visa-free regime.

In order to obtain a patent, migrants must meet numerous requirements within 30 days of their arrival. These include obtaining a migration card, a temporary residence registration, and certificates attesting to their health and knowledge of the Russian language and Russian history and law. They must also pay a monthly patent fee. A migrant needs at least 25,000 rubles (roughly \$350) in order to meet these initial requirements.

Rather than making it easier to navigate the legalization process, the new patent system introduced more complicated bureaucratic procedures and high fees that pushed migrants further into the shadow economy. Some resort to various semilegal and illegal practices, such as buying fake documents. Given these effects, migration scholars and experts often characterize the recent reforms to the Russian migration regime as taking one step forward, two steps back.

\section{EVERYDAY XENOPHOBIA}

Another challenge faced by Central Asian migrants in Russia is the racism they experience in everyday situations across all social settings, including their interactions with government officials, police officers, and border guards.

Expressions of anti-migrant sentiment have been normalized in contemporary Russia's public discourse. The prevalence of such hostility is exemplified by the depiction of Central Asian migrants as "illegals" or gastarbaitery (an adaptation of the German word for "guest worker," which has been given a negative connotation in the Russian context). These racist terms are widely used in the Russian media as well as among ordinary Russian citizens.

In everyday life in Russia, a migrant is defined as a person who does not look Russian, regardless of his or her legal status, citizenship, or period of residence. Migrants are also assumed to be eager to commit crimes. Such racist tropes are reinforced by the media, shaping public opinion and intensifying xenophobic attitudes toward migrants.

The coverage of Central Asian migrants before and after the uprising in Ukraine illustrates this typical media portrayal of migrants as public enemies. Opinion polls in October 2013 showed xenophobia against migrants in Russia at a record high: 73 percent of respondents held the view that the government should restrict the influx of Central Asian migrants and expel "illegals" from the country. Although negative attitudes toward migrants had been common in recent years, the increase in late 2013 was mostly a result of the Moscow mayoral election held during the summer. Candidates competed to deliver the harshest anti-migrant rhetoric. The campaign was widely covered by nationwide television channels, stoking anti-migrant sentiment.

But in 2014, as events in Ukraine unfolded and tension between Russia and the West escalated, the Russian media shifted toward anti-Ukrainian and anti-Western rhetoric. By the summer of 2015, the same survey that had previously recorded high levels of xenophobia found that only 43 percent of respondents thought that Central Asian migrants should be barred from entering Russia. That was a drop of 30 percentage points in two years.

However, recent opinion polls have again recorded rising levels of xenophobia. In September 2019, 72 percent of respondents had an unwelcoming attitude toward migrants in Russia. The growing anti-migrant rhetoric in the Russian media, partly in response to the refugee crisis in Europe in 2015-16, might explain this trend.

Along with everyday xenophobia and frequent police abuse, migrant workers are often victims of fraud perpetrated by employers or by intermediaries who offer help with finding a job, procuring documents, or otherwise navigating the system. All this contributes to a constant sense of insecurity that many migrants experience in their everyday lives as they contend with the pervasive 
threats of discrimination, exploitation, abuse, and deportation.

There is little hope of support from the Russian government. Central Asian migrant workers are simultaneously visible and invisible to the state. It denies migrants access to welfare and an opportunity to voice their concerns, while it exploits their cheap labor. Migrants have become an indispensable part of the Russian labor market.

Migrants put up with these hardships because their earnings in Russia are a vital source of income for impoverished households back in their home countries. Many migrants cling to the illusion that their precarious status is temporarythat after saving enough to buy a house or a car, pay off debt, or celebrate a wedding, they will no longer have to come to Russia for work. In reality, many of them keep returning, and tolerate daily mistreatment on the assumption that their situation is temporary and they will eventually return home for good. They exist in a condition of normalized precarity.

Nonetheless, migrants have informal resources to draw on. Seeking to minimize risks and adapt to their precarious environment, they come to rely on informal safety nets and infrastructures found within many migrant communities. These services have contributed to the development of "parallel communities" in which migrants can seek jobs, accommodation, leisure activities, advice, and other assistance.

Such informal resources are especially helpful for socializing with people from one's home country, or even for quickly collecting money among migrants to finance the repatriation of a deceased countryman's body. Informal channels and networks allow mobility between Russia and Central Asia to remain resilient despite the disruptions caused by economic crises and restrictive immigration laws and policies.

\section{POLITICAL PAWNS}

As some scholars have noted, inconsistencies in Russia's immigration laws may be a result of the conflicting needs and objectives of different interest groups. Liberals and business elites view labor migration as an inevitable and even necessary tool to fill economic and demographic gaps. But siloviks (officials from the military or security establishment) and nationalists see migration as a dangerous and undesirable phenomenon-a security and cultural threat-and demand strict controls. Due to these clashing elite views, seemingly liberal immigration rules coexist with restrictive and punitive measures.

Other scholars see these ambiguities in migration governance as serving the purpose of keeping the number of documented migrants low so that Russian officials can strategically manipulate antimigrant sentiment to gain popular support. Officials often divide immigrants into desirable and undesirable categories based on their cultural and racial backgrounds.

In December 2019, answering a journalist's question at a press conference, President Vladimir Putin stated that Russia needs to take a selective approach in its immigration policies. Those "who know Russian culture and speak the language"in other words, people from Belarus, Ukraine, and Moldova-are welcome, Putin declared. But he added that it is difficult for Central Asian migrants to adapt to Russian society. Putin called for restricting migration from Central Asia to avoid causing "irritation among local residents when they are faced with disrespect for our culture and history."

None of this should give the impression that migrants need Russia but Russia does not need migrants. For domestic political purposes, migration is depicted as a dangerous force that must be contained and controlled. But in fact, Russia needs migrant workers not only because they provide cheap labor, but also because they partly compensate for the country's shrinking population. Migration also gives Moscow leverage to influence neighboring postSoviet countries that are economically dependent on the Russian labor market.

Armenia and Kyrgyzstan joined the Russian-led EEU, which promises free flows of capital, goods, services, and labor among member countries, in hopes that their migrant citizens would face fewer bureaucratic hurdles and lower costs of entry into the Russian labor market. This regional influence makes the EEU one of Russia's most important geopolitical projects in its confrontation with the West.

To take another example of the regional politics of migration, when the Russian military's lease of a base in Tajikistan was about to expire in 2012, one of the concessions that Moscow was willing to grant in exchange for a 30-year extension of the 
was an amnesty for "illegal" Tajik migrants. The two governments also struck an agreement on easing travel and work restrictions for Tajik nationals in Russia.

Russia has also routinely used citizenship as a means of gaining leverage in regional geopolitics. One of the justifications cited by Moscow for its involvement in territorial conflicts with Moldova, Georgia, and Ukraine has been the large number of people in disputed regions of those countriesTransnistria, Abkhazia, South Ossetia, Crimea, Donetsk, and Luhansk-who had received Russian citizenship well before the fighting broke out. Putin has claimed a duty to protect ethnic Russians and Russian speakers outside the motherland. But the distribution of Russian passports to residents of these areas has often coincided with an intensification of conflict.

Citizenship is not just a geopolitical tool for Moscow. Population aging and a shrinking labor force have been a top concern for Russian authorities. In the past three decades, the population shrank by 3.6 million despite the inflow of Russian speakers from other post-Soviet countries in the 1990s and the naturalization of several million new citizens in recent years.

Russia has been easing naturalization rules for more than a decade. In 2018, nearly 270,000 foreigners obtained Russian citizenship. In 2019, the number jumped to almost 500,000. Approximately 300,000 of these new citizens are former Ukrainians; 167,000 of the new passports were issued in Russia's Rostov region, which borders separatist-held areas in eastern Ukraine.

In April 2020, Russia adopted a new law that simplifies the rules for obtaining Russian citizenship. Among other changes, it allows naturalized citizens to retain their original nationality. The previous requirement that applicants give up their citizenship in their home countries deterred many who had resided in Russia for a long period from applying. This kept tens of thousands of migrants with residence permits in limbo, allowing them to continue living and working in Russia but with no viable path to citizenship unless they were willing to cut ties with their home countries (some of which, such as Uzbekistan, prohibit dual citizenship).

Obtaining Russian citizenship lowers the cost of entry into the labor market and provides more secure status. The economic crisis caused by the COVID-19 pandemic will likely increase competition for jobs (including with local Russians), which in turn will encourage more migrants who have lived in Russia for several years to apply for Russian citizenship.

\section{PANDEMIC SHOCK}

The pandemic caught migrant workers in Russia by surprise. As the number of confirmed cases started to soar, the government imposed lockdown measures to contain the virus. On March 18, Russia barred entry for all foreigners, a restriction that remained in place through the spring and into the summer.

Regional authorities were given autonomy to decide how far to go in ordering temporary closures. Since lockdown policies differed from region to region, the scale of job losses among migrants also varied.

In Moscow, the leading destination for migrants, fairly strict lockdown measures were imposed. As many businesses suspended their activities, especially in the service and retail trade sectors, Central Asian migrants were first in line to lose their jobs. Although authorities urged companies not to fire staff during the crisis, few businesses could afford to retain their Russian employees, let alone migrant workers. Tax holidays and incentives offered by the government did little to alleviate most firms' losses. At best, migrants were put on unpaid leave without any guarantee of returning to the same job.

According to Russian immigration rules, migrants must work in the jurisdiction where they obtain their work permits. A migrant who loses a job in Moscow and finds another in a different province has to start over with the process of applying for a new patent. This rule was especially problematic during the lockdown. Many jobless migrants were stuck indoors in large cities like Moscow and St. Petersburg at a time when there was a growing demand for labor in southern regions as spring arrived and the season for agricultural work began.

Job losses among migrants also differed by sector. While most migrants who had been employed in the service and trade sectors had to stay indoors without jobs, construction laborers were allowed to return to work after just a few weeks of confinement. This was partly due to concerns expressed by big businesses over a potential shortage of cheap labor and the suspension of construction projects.

However, the main reason for allowing migrants to return to construction sites was probably the mid-April detection of coronavirus infections at a dormitory housing about 470 migrants outside 
St. Petersburg. The number of confirmed infections at the dorm eventually reached 123. Similar mass outbreaks among migrants also occurred in dormitories in the regions of Murmansk, where 125 were infected, and Bashkortostan, where 68 tested positive. Authorities likely realized that locking down large numbers of migrants might lead to more outbreaks.

Putin urged provincial governors to let migrants return to construction sites. On April 18, he signed a decree allowing migrants to work without permits from March 15 to June 15. Their stays in Russia would be automatically prolonged without the risk of fines or deportation.

Even so, migrants have become one of the most vulnerable social groups in Russia during the pandemic. Many have lost their jobs, while others have been compelled to work on construction sites and in housecleaning and other domestic services, risking their health. If they test positive for COVID-19, migrants have minimal access to health care services.

Central Asian governments organized several charter flights to repatriate their most vulnerable citizens, but tens of thousands were still waiting to return home. Charities and local activists delivered food to those who lost their jobs and were confined inside without any means to feed themselves. Most migrants send almost all of their earnings home to their families, keeping only enough to cover their own basic subsistence costs. Many of them soon ran out of money during the lockdown.

Migrants who kept their jobs and had to commute amid the lockdown were often stopped by police, who checked their identification and travel permits. Migrant rights activists have reported that even when migrants produced all their documents, police officers often accused them of breaching the lockdown rules. In most cases, they were released after paying a bribe.

The collapse of oil prices just before the lockdown measures took effect worsened Russia's economic crisis. Many Russians have lost their jobs, accelerating a long-term decline in living standards. As the unemployment rate increased sharply, Russian authorities started to adopt new rules to ensure that the local population would have priority for employment in skilled jobs.

When competition for scarce jobs intensifies, populists may step up their efforts to stir up xenophobia among the public. Some Russian media outlets have depicted migrants as so desperate to find food that they are prepared to do anything, even resort to crime.

Job losses and reduced earnings among migrants have already resulted in a decline in the remittances they send to their home countries. Central Asian economies have suffered from national lockdown measures and the closure of nonessential businesses. Dwindling intakes of remittances and the weakening of the Russian economy-one of the largest trade partners for Central Asian countriesthreaten to cause more severe damage.

Kyrgyzstan and Tajikistan, the poorest countries in the region, will suffer the most. In 2018, migrant remittances amounted to 33 percent of gross domestic product in Kyrgyzstan and 29 percent in Tajikistan. More than $\$ 8$ billion in remittances was sent to Uzbekistan, Tajikistan, and Kyrgyzstan in 2019. In June 2020, reports indicated that remittances to Central Asian countries in March and April fell by nearly half from the same period the previous year.

Seasonal migrants across Central Asia now find themselves in a difficult situation. They cannot find jobs at home, and they cannot travel to Russia because the borders remain closed. Even if the borders open in the coming months, it will be hard to find jobs in Russia. The labor mar-

ket is expected to stay shrunken for an extended period after the pandemic.

Unlike the Russian economic crises of 2008-9 and 2014-15, when the number of migrants fell sharply but gradually recovered over the next several years, it will take longer for the situation to normalize after the pandemic. The calamity overtook Russia at a time when its economy was already shrinking. Oil prices and the ruble have plummeted; supply and demand chains have ruptured. Amid these economic blows, Russian society faces deepening political repression.

In the short term, as employers try to minimize their costs by hiring employees unofficially to avoid taxes, more and more migrants will be pushed into the shadow economy, increasing the risks of exploitation and deportation. Normalized precarity should no longer be seen as something extraordinary, but rather as a way of life for millions of Central Asian migrants in Russia in the COVID-19 era. 